\title{
A physical sign of stroke sequel on the skeleton of Leonardo da Vinci?
} Figure General view of the sarcophagus of Leonardo da Vinci, with the skeleton in situ, and details of the skull
and associated archaeological artifacts

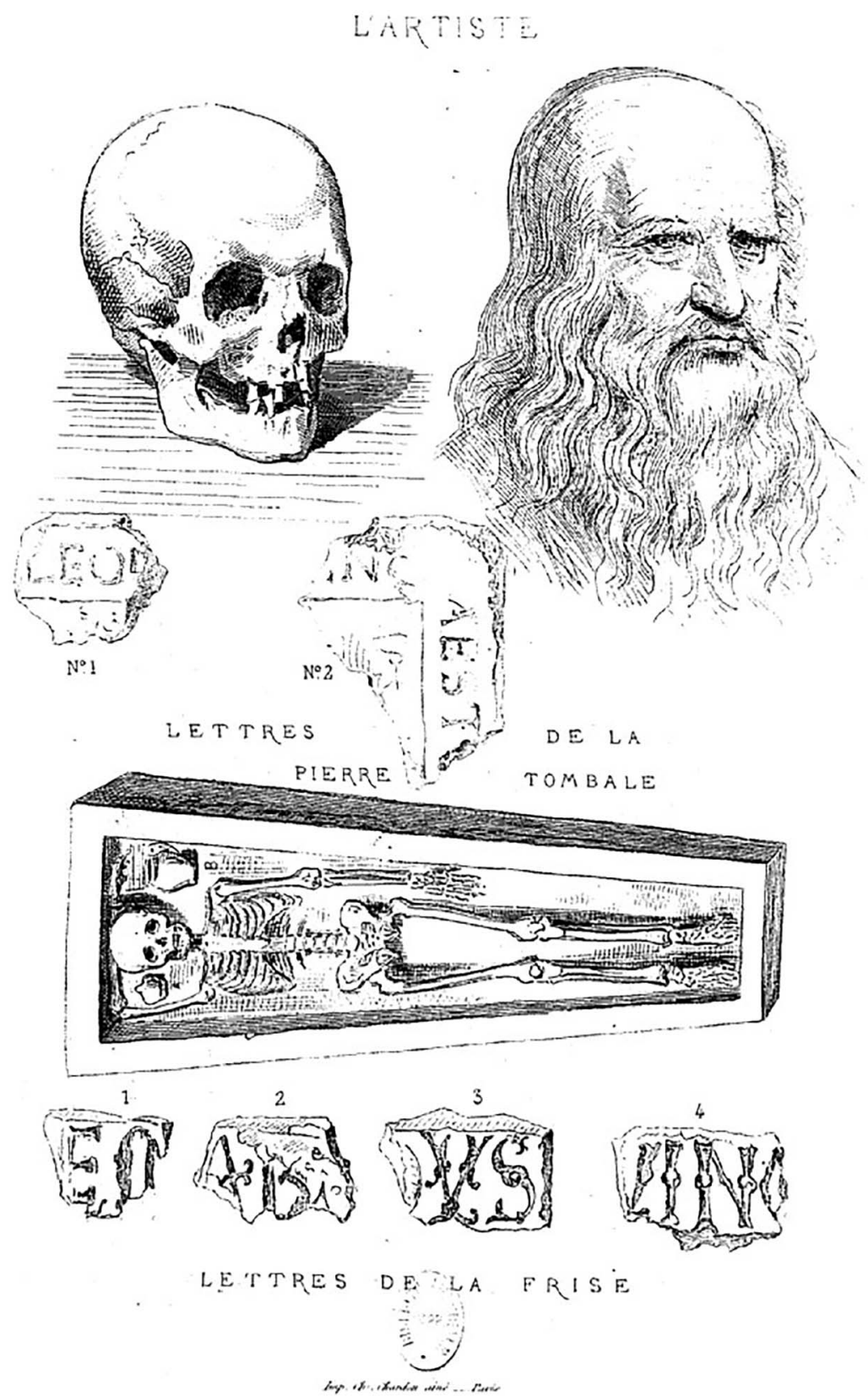

Engraving from L'Artiste (Paris), March 1, 1864, from a drawing by Frans Verhas.

Scholars generally state that Leonardo da Vinci died in 1519 at age 67 of recurrent stroke. One finding may confirm this medical hypothesis: in 1863, the grave of Leonardo was discovered in the Saint-Florentin chapel of Amboise (France), with the skeleton of an old man, tiny fragments of white hair, 8 remaining teeth, and the upper right arm blocked over the skull ${ }^{1}$ (figure). 
The main explication for this atypical position is the presence of a local or regional handicap. Stroke is a possible cause of such anomaly, causing muscular retraction or shoulder dislocation (whose reduction may be difficult or impossible, even postmortem). ${ }^{2}$ A direct examination of the skeleton could complete this anthropologic analysis.

Philippe Charlier, MD, PhD, LittD, Saudamini Deo, LittM

From UFR of Health Sciences (UVSQ \& EA 4569 Paris-Descartes) (P.C., S.D.), Montigny-Le-Bretonneux; and CASH \& IPES (P.C.), Nanterre, France.

Author contributions: Dr. Charlier: study supervision, main writing process, analysis and interpretation. S. Deo: critical revision of the manuscript for important intellectual content.

Study funding: No targeted funding reported.

Disclosure: The authors report no disclosures relevant to the manuscript. Go to Neurology.org for full disclosures.

Correspondence to Dr. Charlier: philippe.charlier@uvsq.fr

1. Prevêt A. La tombe de Léonard à Amboise. In: Charlier P, ed. Actes du 3ème Colloque International de Pathographie. Paris: De Boccard; 2009.

2. Griffin C. Management of the hemiplegic shoulder complex. Top Stroke Rehabil 2014;21:316-318.

\section{Registration Now Open for 2017 AAN Annual Meeting in Boston}

Discover the Annual Meeting everyone's talking about. We changed the entire format and feel of the AAN Annual Meeting for 2016 - and people took notice! We're doing it again in 2017, and adding even more changes to the docket. Register today to experience the value, choice, customization, and innovation that only an AAN Annual Meeting can offer. We look forward to seeing you April 22-28 in Boston. Register today at AAN.com/view/AM17.

\section{BrainPAC}

BrainPAC is the American Academy of Neurology's (AAN) federal political action committee.

- Since its inception, more than 3,600 AAN members have contributed $\$ 2,000,000$ to BrainPAC.

- BrainPAC contributed more than $\$ 600,000$ to individuals who ran for election in 2016, including several first-time candidates.

- During the 2016 congressional election, 92\% of candidates supported by BrainPAC won election to the US Congress.

BrainPAC supports both Democrats and Republicans who support issues important to the practice of neurology and the care of patients with neurologic conditions. US AAN members are invited to learn more at BrainPAC.org. 


\section{Neurology}

\section{A physical sign of stroke sequel on the skeleton of Leonardo da Vinci? Philippe Charlier and Saudamini Deo \\ Neurology 2017;88;1381-1382 \\ DOI 10.1212/WNL.0000000000003799}

\section{This information is current as of April 3, 2017}

Updated Information \& Services

References

Subspecialty Collections

Permissions \& Licensing

Reprints including high resolution figures, can be found at: http://n.neurology.org/content/88/14/1381.full

This article cites 1 articles, 0 of which you can access for free at: http://n.neurology.org/content/88/14/1381.full\#ref-list-1

This article, along with others on similar topics, appears in the following collection(s):

All Cerebrovascular disease/Stroke

http://n.neurology.org/cgi/collection/all_cerebrovascular_disease_strok e

Clinical neurology examination

http://n.neurology.org/cgi/collection/clinical_neurology_examination Forensic neurology

http://n.neurology.org/cgi/collection/forensic_neurology

History of Neurology

http://n.neurology.org/cgi/collection/history_of_neurology

Other Education

http://n.neurology.org/cgi/collection/other_education

Information about reproducing this article in parts (figures,tables) or in its entirety can be found online at:

http://www.neurology.org/about/about_the_journal\#permissions

Information about ordering reprints can be found online:

http://n.neurology.org/subscribers/advertise

Neurology ${ }^{\circledR}$ is the official journal of the American Academy of Neurology. Published continuously since 1951, it is now a weekly with 48 issues per year. Copyright @ 2017 American Academy of Neurology. All rights reserved. Print ISSN: 0028-3878. Online ISSN: 1526-632X.

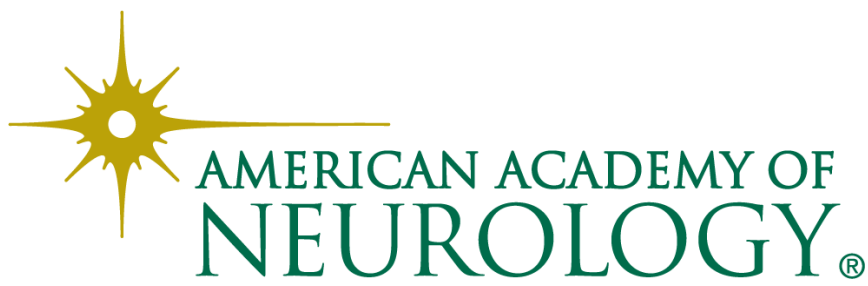

